\title{
Liquid chromatography-tandem mass spectrometry analysis of eicosanoids and related compounds in cell models ${ }^{\text {is }}$
}

\author{
Raquel Martin-Venegas ${ }^{a}$, Olga Jáuregui ${ }^{\mathrm{b}}$, Juan Jose Moreno ${ }^{\mathrm{a}, *}$ \\ a Departament de Fisiologia, Facultat de Farmacia, Universitat de Barcelona, 08028-Barcelona, Spain \\ ${ }^{\mathrm{b}}$ Centres Cientifics i Tecnologics (CCiTUB), Universitat de Barcelona, 08028-Barcelona, Spain
}

\section{A R T I C L E I N F O}

\section{Article history:}

Received 19 August 2013

Received in revised form 7 May 2014

Accepted 8 May 2014

Available online $\mathrm{xxx}$

\section{Keywords:}

LC-MS/MS

Prostaglandins

Leukotrienes

Hydroxyeicosatetraenoic acids

Epoxyeicosatrienoic acids

Cell culture

\begin{abstract}
A B S T R A C T
Enzyme- and free radical-catalyzed oxidation of polyunsaturated fatty acids (PUFAs) produces the eicosanoids, docosanoids and octadecanoids. This large family of potent bioactive lipids is involved in many biochemical and signaling pathways which are implicated in physiological and pathophysiological processes and can be viable therapeutic targets. Liquid chromatography-tandem mass spectrometry (LC-MS/MS) offers selectivity, sensitivity, robustness and high resolution and is able to analyze a large number of eicosanoids in biological samples in a short time. The present article reviews and discusses reported LC-MS/MS methods and the results obtained from their application in cell models. Reliable analytical outcomes are critically important for understanding physiological and pathophysiological cellular processes, such as inflammation, diseases with inflammatory components (e.g., cardiovascular disease, diabetes, metabolic syndrome), as well as cancer. Reported findings obtained by using the LC-MS/MS methodology in cell systems may have important predictive as well as nutritional and pharmacological implications. We conclude that the LC-MS/MS methodology is a versatile and reliable analytical tool for the simultaneous analysis of multiple PUFA-derived metabolites including the eicosanoids in cell culture samples at concentrations on the $\mathrm{pM} / \mathrm{nM}$ threshold, i.e. at baseline and after stimulation.
\end{abstract}

(C) 2014 Elsevier B.V. All rights reserved.

\section{Arachidonic acid cascade: substrates, enzymatic pathways and metabolites}

Lipids constitute a complex family with as many as 180,000 different members. Lipids not only exert a variety of physiological functions, but they also possess different physicochemical properties. As a result, the different lipid subfamilies require separate analysis. Many of these lipids, such as sphingolipids, glycerolipids, oxylipins, endocannabinoids and $\mathrm{N}$-acylethanolamines, constitute an intricate network and play a key role in the mechanisms underlying physiological and pathophysiological processes $[1,2]$.

Polyunsaturated fatty acids (PUFAs) are precursors of oxylipins, a large subfamily of metabolites, endowed with potent bioactivities and which are involved in homeostasis and pathophysiological events. The diversity of PUFAs precursors and metabolic pathways results in a large number of mediators. In fact, new PUFAs-derived

\footnotetext{
This paper is part of the special issues ACIDS edited by Alexander A. ZOERNER and Dimitrios TSIKAS.

* Corresponding author. Tel.: +34 934024505; fax: +34 4035901.

E-mail address: jjmoreno@ub.edu (J.J. Moreno).
}

species are constantly being discovered and their activities remain to be explored.

One of the most widely studied oxylipin groups are the eicosanoids, a group comprising over 100 lipid mediators derived from the 20-carbon PUFAs arachidonic (AA), eicosapentaenoic (EPA) and dihomo- $\gamma$-linolenic (DGLA) acids [3]. Prostaglandins (PGs) and thromboxanes (TXs) of the 2-, 3- and 1-series are generated via the cyclooxygenase (COX) pathway from AA, EPA and DGLA, respectively. Hydroxyeicosatetraenoic acids (HETEs), 4-series leukotrienes (LTs) and 4-series lipoxins (LXs) derive mainly from AA by lipoxygenase (LOX), whereas EPA generates hydroxyeicosapentaenoic acids (HEPEs), 5-series LTs, 5-series LXs and E-series resolvins (RvEs) (Fig. 1). These lipid mediators play both beneficial and detrimental roles in a number of important physiological and pathophysiological processes. They include endothelial function, homeostasis, fever, pain, asthma, atherosclerosis, diabetes, metabolic syndrome, cancer, and they are pro-, anti-inflammatory and pro-resolving agents [4-9]. Epoxyeicosatrienoic acids (EETs) and several HETEs are cytochrome P450 products derived from AA. EETs can be metabolized by epoxide hydrolase to dihydroxyeicosatetraenoic acids (DHETs) [3]. A growing body of work has highlighted their role in cardiovascular disease, hypertension and respiratory disease [10,11]. Finally, 


$\begin{array}{ll}\text { Nomenclature } \\ \text { AA } & \text { Arachidonic acid } \\ \text { APCI } & \text { Atmospheric-pressure chemical ionization } \\ \text { CE } & \text { Collision energy } \\ \text { COX } & \text { Cyclooxygenase } \\ \text { DHA } & \text { Docosahexaenoic acid } \\ \text { DHET } & \text { Dihydroxyeicosatetraenoic acid } \\ \text { DGLA } & \text { Dihomo- }- \text {-linolenic acid } \\ \text { DP } & \text { Declustering potential } \\ \text { EIA } & \text { Enzyme immunoassay } \\ \text { EPA } & \text { Eicosapentaenoic acid } \\ \text { EET } & \text { Epoxyeicosatrienoic acid } \\ \text { ESI } & \text { Electrospray ionization } \\ \text { HDHA } & \text { Hydroxydocosahexaenoic acid } \\ \text { HEPE } & \text { Hydroxyeicosapentaenoic acid } \\ \text { HETE } & \text { Hydroxyeicosatetraenoic acid } \\ \text { HODE } & \text { Hydroxyoctadecadienoic acid } \\ \text { IS } & \text { Internal standard } \\ \text { LC } & \text { Liquid chromatography } \\ \text { LE } & \text { Liquid extraction } \\ \text { LT } & \text { Leukotrienes } \\ \text { LOX } & \text { Lipoxygenase } \\ \text { MRM } & \text { Multiple reaction monitoring } \\ \text { MS } & \text { Mass spectrometry } \\ \text { MS/MS } & \text { Mass spectrometry/mass spectrometry (tandem } \\ & \text { mass spectrometry) } \\ \text { NSAID } & \text { Non-steroidal anti-inflammatory drug } \\ \text { PG } & \text { Prostaglandin } \\ \text { PD } & \text { Protectin } \\ \text { PP } & \text { Protein precipitation } \\ \text { PUFA(s) } & \text { Polyunsaturated fatty acid(s) } \\ \text { QqQ } & \text { Triple quadrupole } \\ \text { RT } & \text { Retention time } \\ \text { Rv } & \text { Resolvin } \\ \text { RvDs } & \text { D-series resolvins } \\ \text { RvEs } & \text { E-series resolvins } \\ \text { SPE } & \text { Solid-phase extraction } \\ \text { TX } & \text { Thromboxane } \\ & \end{array}$

isoprostanes are generally believed to be non-enzymatic metabolites of AA. They are related to oxidative stress and involved in several diseases such as asthma [12] and cystic fibrosis [13].

In addition to the eicosanoids, two other groups of lipids need to be considered. The docosanoids are LOX-derived metabolites from docosahexaenoic acid (DHA) and include hydroxydocosahexaenoic acids (HDHAs), maresins, protectins (PD) and D-series resolvins (RvDs) involved in the resolution of inflammation [14]. The octadecanoids are LOX-derived metabolites from linoleic acid and include hydroxyoctadecadienoic acids (HODEs) [15], metabolites involved in a variety of disorders such as atherosclerosis, thrombosis, inflammation and cancer $[8,9]$ (Fig. 1).

Comprehensive understanding of how these compounds affect human health and how they are involved in pathophysiological processes requires insight into their biosynthesis and metabolism, and demands their reliable quantification in biological samples. However, as oxylipins and other eicosanoids and related compounds are present at very low levels in tissues and cell systems, their measurement requires highly sensitive and specific analytical methods. Numerous analytical methods have been reported to enable large-scale profiling of lipid species. However, many of these analytical methods often lack specificity. Other assays allow at best semi-quantitative analysis of eicosanoids in biological samples (for a review see Ref. [16]). In the following sections we will discuss available analytical methods for eicosanoid analysis in cell systems from various analytical perspectives. Yet, our focus will be on LC-MS/MS and its biological applications.

\section{Eicosanoid analysis in cell cultures: advantages and drawbacks}

Unequivocal characterization and reliable quantification of oxylipins such as eicosanoids and related compounds requires analytical approaches that combine unique selectivity/specificity for the structural characterization of a large number of structurally similar compounds with high sensitivity for their quantification in biological systems at physiologically relevant concentrations which are in the $\mathrm{pM} / \mathrm{nM}$-range. It may results from these requirements that quantification of eicosanoids faces serious challenges and limitations, both with respect to purely analytical issues (e.g., poor specificity, low sensitivity, cross-over and cross-talk effects, and time-consuming analysis) and to cost issues.

In the past, only a small number of eicosanoids and other PUFAs-derived oxygenated mediators were analyzed by enzymelinked immunoassay (EIA) and radio-immunoassay (RIA). These methodologies can measure only one metabolite at a time. This restricts the amount of biological information obtained, and sample volume tends to be a limiting factor. Moreover, immunological assays lack selectivity, may be subject to cross-reactivity, and are commercially available for only few certain eicosanoids $[17,18]$.

Gas chromatography coupled to mass spectrometry (GC-MS) or tandem mass spectrometry (GC-MS/MS) has also been successfully applied in eicosanoid research [19]. GC-MS and GC-MS/MS require multiple derivatization in order to increase volatility and thermal stability. These prerequisites limit a general application of these approaches. Thus, thermally labile compounds such as EETs cannot be sensitively determined by GC-MS or GC-MS/MS, whereas amino acids-containing eicosanoids such as the cysteinyl leukotrienes can not be analyzed by these techniques because no derivatization strategy is available [20], except they are desulphurized before derivatization [19]. HPLC with fluorescence detection also requires derivatization [21], whereas HPLC with UV absorbance detection lacks sensitivity and is applicable only to a limited number of UV-light absorbing analytes. Capillary electrophoresis has been reported to allow measurement of EETs/DHETs after derivatization [22,23]. HPLC coupled to tandem mass spectrometry (MS/MS), i.e., LC-MS/MS, is now regarded as the method of choice for highthroughput screening of inherited metabolic disorders, as well as for the measurement of exogenous and endogenous substances including certain hormones, particularly those which require high accuracy, specificity and sensitivity [24]. LC-MS/MS has also been proven to be a versatile analytical platform for assays of large numbers of lipid mediators due to its higher sensitivity (pg-range) and specificity with reduced sample preparation and analysis time [25], constitute actually the most commonly technique in lipidomics [26-28]. A common approach is to focus metabolic profiling efforts on a group of structurally related compounds with common physicochemical properties such as oxylipins [29]. However, if LC-MS/MS is to become more attractive than other methodologies, such as EIA, it must compete not only on quality grounds but also in terms of test price. Herein resides in one of the problems, since LC-MS/MS instruments are expensive and require additional infrastructure and dedicated technicians and personnel with an academic background. When comparing LC-MS/MS and EIA applications we found that savings could be made both in relation to reduced time for sample preparation/analysis and lower reagent costs. These savings were greater when we increased the number of eicosanoids analysed per sample, or the number of 


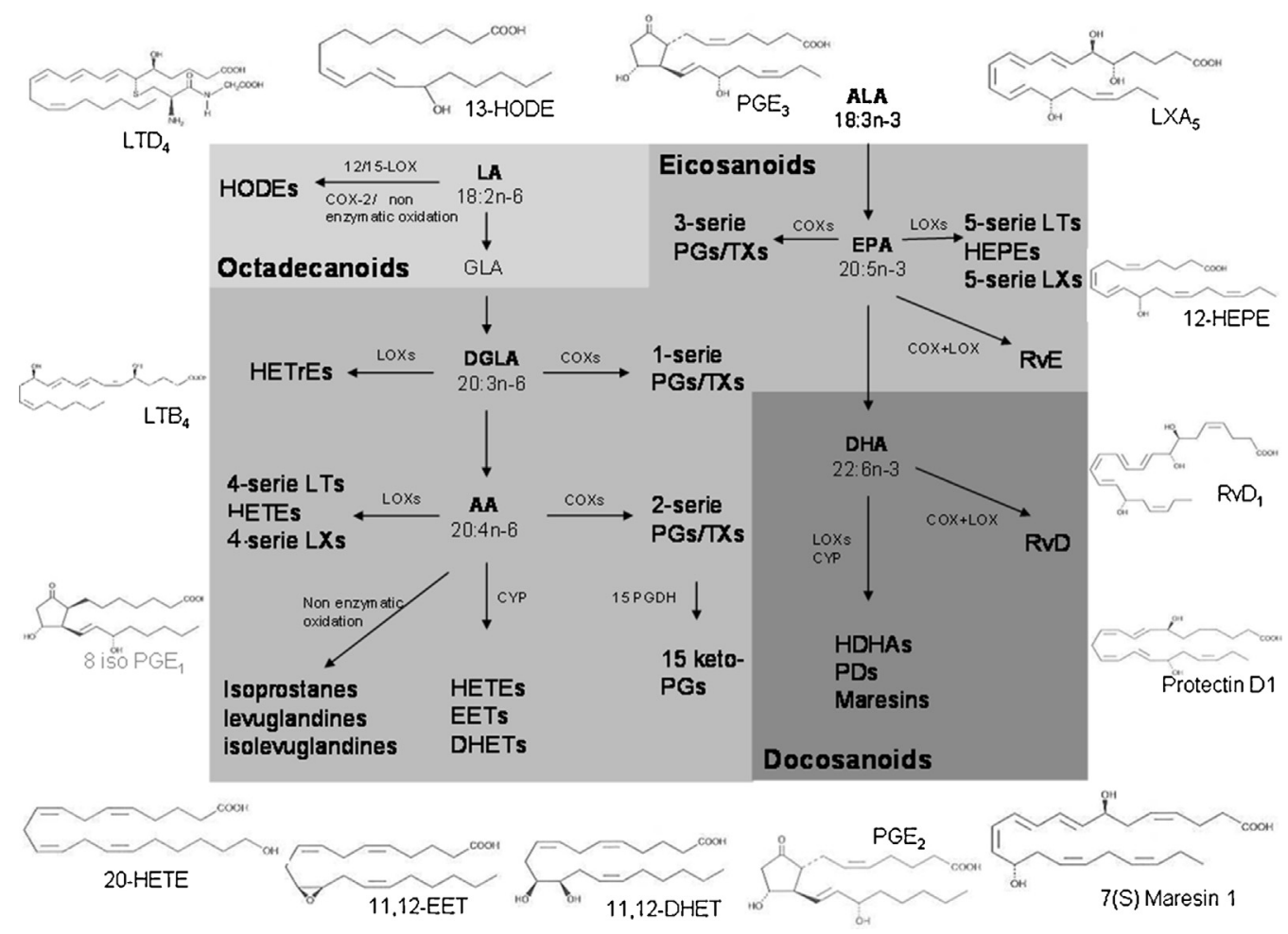

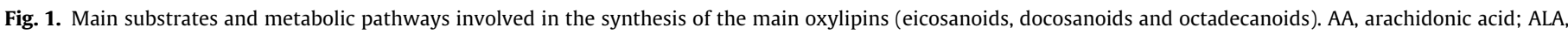

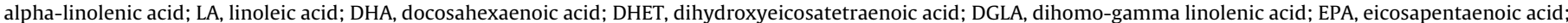

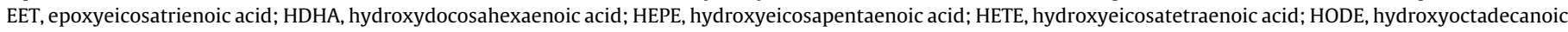
acid; LT, leukotriene; LX, lipoxin; PD, protectin; PG, prostaglandin; Rv, resolvin; TX, thromboxane.

samples. Although several methods of eicosanoid quantification have been described in the literature they tend to focus on a small number of molecules usually of an eicosanoid family such as prostaglandins [30-32], leukotrienes [33] or HETEs [34]. Recently, however, methods have been proposed in which a high number of eicosanoids are quantified simultaneously [35-41]. Simultaneous analysis of several pathways is important for obtaining a holistic picture of the role of the AA cascade in physiological processes or different disease states. The present review briefly summarizes and discusses the state of the art and the challenges faced when measuring multiple eicosanoids and related compounds by the robust and rapid LC-MS/MS analytical methods in cell systems.

\section{LC-MS/MS analysis of eicosanoids in cell cultures}

Cell culture is widely and increasingly used as a substitute for animal experimentation and to study the mechanisms involved in physiological and pathophysiological processes. The biosynthesis of eicosanoids and related mediators in cell cultures depends on the availability of the substrate and of the respective enzymes which are expressed by cells. Thus, oxylipins present in cell cultures mainly depend on the enzymatic AA cascade machinery. Some cell types synthesize a limited number of eicosanoids, whereas others are rich in enzymatic pathways for the synthesis of numerous eicosanoids. In this context, LC-MS/MS methodology is invaluable. An overview of validated LC-MS/MS methods for the analysis of eicosanoids and related compounds in cell lysates or cell supernatants is given in Table 1. Our attention was especially focused on the number and kind of eicosanoids analyzed, as well as on the most important aspects of the methodology employed. These issues are discussed in the following sections.

\subsection{Sample preparation conditions}

Although the instability of some prostaglandins was reported in 1983 by Fitzpatrick and Wynalda [52], little is known about the stability of the majority of the eicosanoids in aqueous solutions, despite their extensive use under in vitro experimental conditions. Schmidt et al. [53] found that prostaglandins were stable at room temperature in methanol, water and formic acid. However, they did not investigate their stability in biological fluids or cell cultures. Maddipati and Zhou [54] reported that PGs, LTs, HETEs, HODEs and EETs exhibited different degrees of stability, with the majority of them maintaining structure integrity. Interestingly, they observed that eicosanoids are significantly stabilized by the presence of albumin in culture media. Cao et al. [31] showed that $\mathrm{PGE}_{2}$ was degraded substantially in cell culture medium after storage for $24 \mathrm{~h}$ at room temperature or for 4 weeks at $-20^{\circ} \mathrm{C}$ in cell culture medium. It is worth mentioning that some eicosanoids, such as $\mathrm{LTD}_{4}$ or those derived from EPA and have a high number of double bounds, are substantially less stable than $\mathrm{PGE}_{2}$. Thus, if quantitative analysis of eicosanoids can not be carried out soon after sample collection, cell culture samples are best stored at $-80^{\circ} \mathrm{C}$ rather than at $-20^{\circ} \mathrm{C}$. Eicosanoids extracted from cell culture samples are stored at best in an organic solvent at $-80^{\circ} \mathrm{C}$ and in the dark. To prevent loss of eicosanoids in samples due to surface adhesion, the contact time between samples and plastic ware as well as their surface should be reduced to a minimum, and samples should be handled on ice at any time.

\subsection{Preparation of stock solutions and standards}

A unique feature of LC-MS/MS and other mass spectrometrybased techniques is the used of stable-isotope labelled analogs 
Table 1

Overview of HPLC-MS/MS methods for the analysis of eicosanoids and related compounds in cell systems.

\begin{tabular}{|c|c|c|c|c|c|c|c|c|c|c|}
\hline \multirow[b]{2}{*}{ Cell line (sample) } & \multirow[b]{2}{*}{$\begin{array}{l}\text { Eicosanoids } \\
\text { analyzed } \\
\text { (number) }\end{array}$} & \multirow[b]{2}{*}{$\begin{array}{l}\text { Internal } \\
\text { standard }\end{array}$} & \multicolumn{2}{|l|}{ Extraction } & \multicolumn{3}{|l|}{ HPLC } & \multicolumn{3}{|c|}{ Mass spectrometry } \\
\hline & & & Method & Recovery & Column & Elution solvent & Elution time (min) & Method & Analytical features & Ref. \\
\hline $\begin{array}{l}\text { Caco-2 cells } \\
\text { (supernatant) }\end{array}$ & $\begin{array}{l}\text { PGs (3) } \\
\text { LTs (2) } \\
\text { HETEs (4) } \\
\text { EETs (4) } \\
\text { TXB } 2 \\
\text { 5-Oxo-ETE } \\
\text { LXs (2) } \\
\text { 5,6-DiHETE } \\
\text { 18-HEPE } \\
\text { HDoHES (2) } \\
\text { PDx } \\
\text { RvD1 } \\
\text { 7-MaR1 }\end{array}$ & Deuterated & SPE (C18 cartritge) & & ZorBAX SB-C18 & $\begin{array}{l}\text { Acetonitrile/ } \\
\text { Water/ } \\
\text { Formic acid }\end{array}$ & 12 & $\begin{array}{l}\text { ESI } \\
\text { negative ion } \\
\text { QqQ } \\
\text { MRM }\end{array}$ & $\begin{array}{l}\text { LLOD } \\
(0.01-15 \mathrm{ng} / \mathrm{ml}) \\
\text { LLOQ } \\
(0.03-31 \mathrm{ng} / \mathrm{ml})\end{array}$ & [38] \\
\hline $\begin{array}{l}\text { Caco-2 cells } \\
\text { (supernatant) }\end{array}$ & $\begin{array}{l}\text { PGs (2) } \\
\text { LTs (2) } \\
\text { HETEs (4) } \\
\text { EETs (4) } \\
\text { DHETs (2) } \\
\text { 13-HODE }\end{array}$ & Deuterated & SPE (Sep-Pack C18) & $38-100 \%$ & $\begin{array}{l}\text { Polarity dC } 18 \\
(150 \times 2.1 \mathrm{~mm} \text {, } \\
5 \mu \mathrm{m})\end{array}$ & $\begin{array}{l}\text { Acetonitrile/ } \\
\text { Water/ } \\
\text { Formic acid }\end{array}$ & 20 & $\begin{array}{l}\text { ESI } \\
\text { negative ion } \\
\text { QqQ } \\
\text { MRM }\end{array}$ & $\begin{array}{l}\text { LLOD }(1-95 \mathrm{pg} / \mathrm{ml}) \\
\text { LLOQ } \\
(40-316 \mathrm{ng} / \mathrm{ml})\end{array}$ & [41] \\
\hline $\begin{array}{l}\text { 3T6 cells } \\
\quad \text { (supernatant) }\end{array}$ & $\begin{array}{l}\text { PGs (2) } \\
\text { LTs (2) } \\
\text { HETEs (4) } \\
\text { EETs (4) } \\
\text { DHETs (2) } \\
\text { 13-HODE }\end{array}$ & Deuterated & SPE (Sep-Pack C18) & $38-100 \%$ & $\begin{array}{l}\text { Polarity dC } 18 \\
(150 \times 2.1 \mathrm{~mm} \text {, } \\
5 \mu \mathrm{m})\end{array}$ & $\begin{array}{l}\text { Acetonitrile/ } \\
\text { Water/ } \\
\text { Formic acid }\end{array}$ & 20 & $\begin{array}{l}\text { ESI } \\
\text { negative ion } \\
\text { QqQ } \\
\text { MRM }\end{array}$ & $\begin{array}{l}\text { LLOD }(1-95 \mathrm{pg} / \mathrm{ml}) \\
\text { LLOQ } \\
(40-316 \mathrm{ng} / \mathrm{ml})\end{array}$ & [36] \\
\hline $\begin{array}{l}\text { LoVo cells (cell } \\
\text { lysate) }\end{array}$ & $\begin{array}{l}\mathrm{PGE}_{2} \\
\text { HETEs (2) } \\
\text { EETs (2) }\end{array}$ & $\begin{array}{l}\text { Deuterated } \\
\text { Carbon } 13\end{array}$ & $\begin{array}{l}\text { SPE } \\
\text { (Oasis HLB) }\end{array}$ & & $\begin{array}{l}\text { Chiralpak AD-H } \\
(250 \times 4.6 \mathrm{~mm} \text {, } \\
5 \mu \mathrm{m})\end{array}$ & $\begin{array}{l}\text { Methanol } \\
\text { /Isopropanol } \\
\text { /Hexane }\end{array}$ & $\begin{array}{l}37 \\
37\end{array}$ & $\begin{array}{l}\text { APCI } \\
\text { negative ion } \\
\text { QqQ }\end{array}$ & & $\begin{array}{l}{[42]} \\
{[42]}\end{array}$ \\
\hline $\begin{array}{l}\text { HCA-7 Colony } 29 \\
\text { cells (cell lysate) }\end{array}$ & 11-oxo-EET & $\begin{array}{l}\text { Deuterated } \\
\text { Carbon } 13\end{array}$ & $\begin{array}{l}\text { SPE } \\
\text { (Oasis HLB) }\end{array}$ & & $\begin{array}{l}\text { Chiralpak AD-RH } \\
(150 \times 4.6 \mathrm{~mm} \text {, } \\
5 \mu \mathrm{m})\end{array}$ & $\begin{array}{l}\text { Methanol/ } \\
\text { Water/ } \\
\text { Formic }\end{array}$ & & $\begin{array}{l}\text { MRM } \\
\text { APCI } \\
\text { negative ion } \\
\text { QqQ } \\
\text { MRM }\end{array}$ & & \\
\hline $\begin{array}{l}\text { Hepa-1c1c7 (cell } \\
\text { lysate) }\end{array}$ & $\begin{array}{l}\text { EETs(6) } \\
\text {-enantiomers- }\end{array}$ & Carbon 13 & $\begin{array}{l}\text { PP } \\
\text { (cloroform/ } \\
\text { methanol) }\end{array}$ & & $\begin{array}{l}\text { Chiralpak AD-H } \\
(250 \times 4.6 \mathrm{~mm} \text {, } \\
5 \mu \mathrm{m})\end{array}$ & $\begin{array}{l}\text { Hexanes } \\
\text { /2-propanol }\end{array}$ & 20 & $\begin{array}{l}\text { APCI } \\
\text { negative ion } \\
\text { MRM }\end{array}$ & $\begin{array}{l}\text { LLOD (100-800 fg) } \\
\text { LLOQ (0.02 ng) }\end{array}$ & [43] \\
\hline $\begin{array}{l}\text { RAW264.7 and } \\
\text { CT26 cells } \\
\text { (supernatant) }\end{array}$ & HETES & & $\begin{array}{l}\text { SPE } \\
\text { (Waters HLB) }\end{array}$ & & $\begin{array}{l}\text { Waters Synmetry } \\
\text { C18 }(250 \times 4.6 \mathrm{~mm} \text {, } \\
5 \mu \mathrm{m})\end{array}$ & $\begin{array}{l}\text { Acetonitrile/ } \\
\text { Water/ } \\
\text { Acetic acid }\end{array}$ & 20 & $\begin{array}{l}\text { ESI } \\
\text { negative ion } \\
\text { MRM }\end{array}$ & & [44] \\
\hline $\begin{array}{l}\text { Bovine retinal } \\
\text { microvascular } \\
\text { endothelial cells } \\
\text { (cell lysate) }\end{array}$ & EETs (4) & Deuterated & $\begin{array}{l}\mathrm{LE} \\
\text { (hexane/ } \\
\text { ethyl acetate) }\end{array}$ & & $\begin{array}{l}\text { Gemini C18 } \\
(150 \times 2 \mathrm{~mm}, 5 \mu \mathrm{m})\end{array}$ & & & MRM & & [45] \\
\hline $\begin{array}{l}\text { A549 and RAW264.7 } \\
\text { cells (supernatant) }\end{array}$ & PGs (2) & Deuterated & $\begin{array}{l}\text { LE } \\
\text { (hexane/ } \\
\text { ethyl acetate) }\end{array}$ & $75-95 \%$ & $\begin{array}{l}\text { Luna phenyl-hexyl } \\
(150 \times 2 \mathrm{~mm}, 3 \mu \mathrm{m})\end{array}$ & $\begin{array}{l}\text { Acetonitrile/ } \\
\text { Ammonium acetate }\end{array}$ & 10 & $\begin{array}{l}\text { ESI } \\
\text { negative ion } \\
\text { QqQ } \\
\text { MRM }\end{array}$ & $\begin{array}{l}\operatorname{LLOD}(20 \mathrm{pg} / \mathrm{ml}) \\
\operatorname{LLOQ}(100 \mathrm{pg} / \mathrm{ml})\end{array}$ & [31] \\
\hline $\begin{array}{l}\text { Squamous } \\
\text { carcinoma cell } \\
\text { lines of the head } \\
\text { and neck (cell } \\
\text { lysate and } \\
\text { supernatant) }\end{array}$ & $\begin{array}{l}\mathrm{PGE}_{2} \\
\text { HETE (3) } \\
13-\mathrm{HODE}\end{array}$ & Deuterated & $\begin{array}{l}\text { LE -cell lysate- } \\
\text { (hexane/ } \\
\text { ethyl acetate) } \\
\text { SPE -supernatant- } \\
\text { (Sep-Pak C18) }\end{array}$ & & $\begin{array}{l}\text { Luna phenyl-hexyl } \\
(150 \times 2 \mathrm{~mm}, 3 \mu \mathrm{m})\end{array}$ & $\begin{array}{l}\text { Methanol / } \\
\text { Ammonium acetate }\end{array}$ & & ESI & & [46] \\
\hline
\end{tabular}




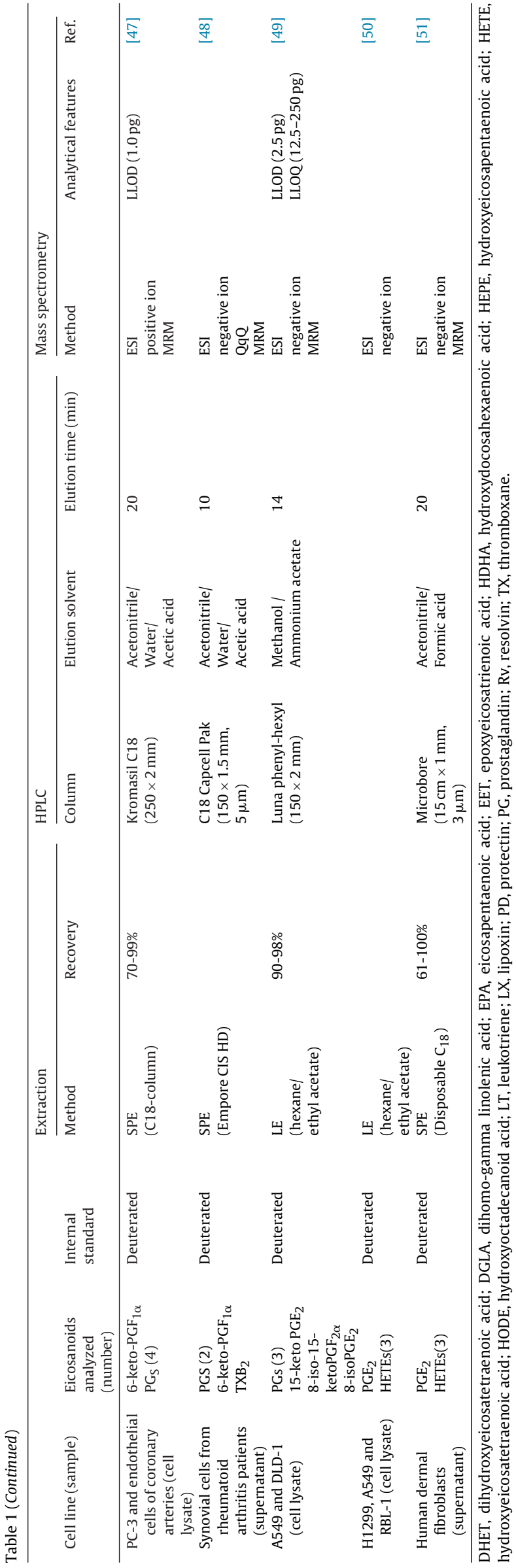

of the analytes as internal standards (IS). Analytes labelled with a sufficient number of deuterium $\left({ }^{2} \mathrm{H}\right)$ or ${ }^{13} \mathrm{C}$ atoms have almost identical physicochemical properties with their unlabelled analogs and provide high accuracy and precision. This is of particular importance in LC-MS/MS, where matrix and ionization effects may play an important role, for instance may differentially affect the target eicosanoid and its IS. With increasing demand for eicosanoids in recent years, the number of suppliers of stableisotope eicosanoids has increased (Table 1). Today, a large number of stable-isotope eicosanoids is commercially available, with the number of deuterium-labelled eicosanoids being by far higher than that of ${ }^{13} \mathrm{C}$-labelled analogs which are moreover substantially more expensive. On the other hand, it should be remembered that deuterium-labelled standards pose the potential risk of hydrogendeuterium exchange, with olefinic deuterium atoms often being easier exchangeable that aliphatic deuterium atoms. Both stableisotope labeled analogs and biological samples such as homogenate should be left on ice and in the dark for few minutes before performing eicosanoid extraction.

\subsection{Eicosanoid extraction and recovery}

Sample clean-up and eicosanoid isolation are dependent upon the origin of the sample. Thus, samples from cell cultures such as cell supernatants and lysates are "cleaner" than serum, plasma or tissue homogenate samples. Several different sample cleanup procedures can be used for this purpose, including protein precipitation (PP), liquid-liquid extraction (LE), immunoaffinity chromatography (IAC) and solid-phase extraction (SPE).

PP by adding two volumes of water-miscible organic solvents such as methanol generally provides high extraction efficiency ( $>90 \%$ ). However, because eicosanoids can be precipitated together with proteins on which they bind unspecifically, this extraction method is not very suitable for analysis of eicosanoids present in the samples at very low concentrations.

LE performed with water-immiscible organic solvents such as ethyl acetate, dichloromethane and hexane-ethyl acetate shows reasonable recovery for PGs, HETEs and EETs, but not for more hydrophilic compounds such as the cysteinyl LTs.

IAC has been widely and is increasingly used as a sample preparation step for quantitative analysis of autacoids, drugs and toxins. The higher specificity of this technique derives from the use of one or more chemically immobilized antibodies raised against the analyte/analytes to be extracted from the biological sample. Eicosanoids that are generally present in various samples in the pM-range are attractive candidates for IAC coupled to LC-MS/MS. Immunoaffinity purification can be regarded the "gold standard" for the extraction and isolation of endogenous compounds [55]. However, IAC columns and sorbents are commercially available for a very small number of eicosanoids [19]. This limits the applicability of this extraction method to a wider spectrum of different eicosanoids in biological samples.

At present, the most commonly used method for sample preparation in eicosanoid analysis by LC-MS/MS is SPE. Traditionally, SPE has been widely used for the analysis of eicosanoids in cell culture supernatants and lysates. Protein precipitation is often performed prior to SPE, including in samples rich in foetal serum [36,38]. Several packing materials with different characteristics are commercially available for SPE of eicosanoids. The most frequently used materials are lipophilic reverse-phase materials such as octadecyl silica, mixed-phase materials or hydrophilic normal-phase materials such as silica. A comparison indicated that DSC-C8 cartridges provide relatively better extraction recovery than the cartridges of the type Superclean LC-8, Sep-Pack C18 or Oasis HLB [37]. The SPE procedures used in the LC-MS/MS analysis of eicosanoids resemble those used for conventional HPLC analysis. However, in LC-MS/MS 
analysis extra care should be taken to prevent co-extraction of compounds that may cause ion suppression, such as the phospholipids [56].

IAC or SPE are not merely methods of eicosanoid extraction from biological samples. Moreover, IAC and SPE are usually applied to concentrate eicosanoids prior to LC-MS/MS analysis. Extraction rates of $90 \%$ or higher can be achieved by SPE. However, extraction yield may vary between $35-100 \%$, depending upon different factors including the physicochemical properties of the eicosanoid, the brand and type of the packing material, as well as upon the extraction protocol used (Table 1).

Finally, after evaporation of the solvent(s) used to elute the eicosanoids from SPE or IAC cartridges, the residue is commonly reconstituted in $100 \mu \mathrm{l}$ ethanol-water $(70: 30, \mathrm{v} / \mathrm{v})$. Addition of a small amount of water may be useful to improve chromatography. It is advisable to perform LC-MS/MS as soon as possible upon sample reconstitution. Alternatively, extracts can be stored frozen at $-80^{\circ} \mathrm{C}$ until analysis.

\subsection{Liquid chromatography}

Over the years, it has become increasingly apparent that accurate measurement depends on appropriate LC separation before selective MS/MS separation and detection. This particularly applies to the large family of the eicosanoids which furthermore consist of numerous isomeric and isobaric compounds. Oxygenated PUFA mediators are hydroxylated unsaturated carboxylic acids. Typically, they are separated chromatographically by polarity mostly on $\mathrm{C} 18$ columns. The injection volume usually ranges between 2 and $10 \mu \mathrm{l}$, the flow rate is $0.2 \mathrm{ml} / \mathrm{min}$, and an acidified methanolor acetonitrile-based mobile phase system is used. For ionizable analytes such as the eicosanoids, the mobile phase $\mathrm{pH}$ may have a significant impact on LC in terms of retention, resolution and selectivity, which may finally impair sensitivity [57]. Least hydrophobic eicosanoids such as PGs and LTs elute earlier and largely independent of the mobile phase $\mathrm{pH}$. More hydrophobic eicosanoids such as HETEs/EETs require, on the other hand, higher mobile phase $\mathrm{pH}$ and higher fractions of organic solvents in the mobile phase(s) for elution.

With regard to COX- and LOX/CYP-derived mediators, many different protocols are available. Combination of protocols from various groups is problematic. From our experience many eicosanoids elute early and share common fragment ions. As an example, $\mathrm{PGE}_{2}$ and $\mathrm{PGD}_{2}$ are isomeric and isobaric. Satisfactory $\mathrm{LC}$ separation is required for their accurate identification and quantification in biological samples in which they accompany each other. Acetonitrile-based mobile phases are probably the best way for optimal LC separation of isobaric species. Yet, a more polar solvent such as methanol is likely to be required to achieve sharper peaks and improve resolution of HETEs [58], otherwise peak broadening may occur.

Fig. 2 shows that eicosanoids usually elute in the order: PGs, LTs, DHETs, HETEs, HODEs and EET. The total analysis time mainly depends on the number and groups/classes of eicosanoids to be separated and may range about $10-20$ min or even longer.

Numerous eicosanoids have two enantiomers which may differ in their biological activity. Thus, 5(R)-HETE and 5(S)-HETE have been shown to differ in their potency: $5(R)$-HETE is a more powerful chemotactic agent than 5(S)-HETE [59]. On the other hand, 13(R)-HODE and 13(S)-HODE have diametrically opposite biological activities: 13(S)-HODE is antiproliferative/apoptotic, whereas $13(R)$-HODE is mitogenic [60]. Discrimination between $13(R)$ HODE and 13(S)-HODE is for this reason indispensable and requires the use of chiral columns. Accordingly and in order to better understand the role of oxylipins in health and disease, chiral-based LC and

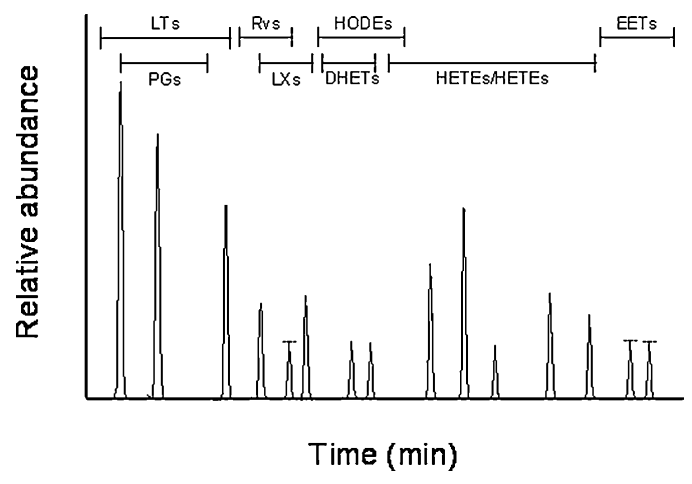

Fig. 2. Schematic illustration of the elution zones of the main eicosanoid groups and related compounds in LC-MS/MS.

explicit mention of the chiral species being analyzed and quantified would be required.

\subsection{Mass spectrometry}

LC-MS/MS analysis of eicosanoids is usually performed on HPLC systems coupled to triple quadrupole (QqQ) or ion trap mass spectrometers using electrospray ionization (ESI) or atmosphericpressure chemical ionization (APCI) [61]. QqQ mass spectrometers allow currently the most sensitive quantitative analysis of eicosanoids by LC-MS/MS. Eicosanoids that possess a free carboxylic group generate in the negative-ion mode a prominent molecular ion due to $[\mathrm{M}-\mathrm{H}]^{-}$. The ion chemistry involved in the generation of products ions from numerous eicosanoids has been reviewed by Murphy et al. [62]. Multiple reaction monitoring (MRM) of specific and abundant product ions produced from $[\mathrm{M}-\mathrm{H}]^{-}$is usually applied for maximum sensitivity in quantitative analysis of eicosanoids by LC-MS/MS. Table 2 summarizes reported precursor and product ions used for the quantification of eicosanoids and related compounds by LC-MS/MS. Inclusion of additional precursor/fragment transitions in MRM may ensure the specificity of the detected eicosanoid and accuracy of its quantification.

\subsection{Method validation}

Although MS-based methods possess high specificity, all analytical methods including those based on MS such as LC-MS/MS require thorough method validation in terms of selectivity, sensitivity, accuracy, precision and reproducibility, and matrix-effects [63].

Calibration curves of eicosanoid standards have shown excellent linearity over a concentration range of $0.1-1000 \mathrm{pg} / \mu \mathrm{l}$, with correlation coefficients close to unity. Given that eicosanoid concentration may reach in cell cultures concentrations as high as $0.1-1 \mu \mathrm{M}(30-300 \mathrm{pg} / \mu \mathrm{L})$, it is advisable to perform different calibration curves for each eicosanoid with a concentration range related to the eicosanoid concentration expected in the samples.

Lower limit of detection (LLOD) and lower limit of quantitation (LLOQ) should also be determined for each eicosanoid and experimental condition of LC-MS/MS in the frame of method validation. LLODs of $0.01-1 \mathrm{ng} / \mathrm{ml}$ and LLOQs of $0.1-3 \mathrm{ng} / \mathrm{ml}$ have frequently been reported for many eicosanoids with the exception of EETs which have higher LLOD and LLOQ values [36-38]. Our own findings are comparable with those reported by other authors in similar experimental conditions (Table 1) and fall within the range of eicosanoid concentrations usually measured in cell lysates and cell supernatants. 
Table 2

Precursor and Product ions of octadecanoids, eicosanoids, docosanoids and deuterated standards.

\begin{tabular}{|c|c|c|}
\hline & Precursor ion $(m / z)$ & Product ion $(\mathrm{m} / \mathrm{z})$ \\
\hline \multicolumn{3}{|l|}{ Octadecanoids } \\
\hline 9-HODE & 295 & 123 \\
\hline 13-HODE & 295 & 277 \\
\hline 13-HODE- $\mathrm{d}_{11}$ & 300 & 198 \\
\hline \multicolumn{3}{|l|}{ Eicosanoids } \\
\hline $\mathrm{PGE}_{1}$ & 353 & 317 \\
\hline 6-keto $\mathrm{PGE}_{1}$ & 367 & 143 \\
\hline $\mathrm{PGD}_{1}$ & 353 & 317 \\
\hline 6-keto $\mathrm{PGF}_{1 \alpha}$ & 369 & 163 \\
\hline $\mathrm{PGB}_{2}$ & 333 & 175 \\
\hline $\mathrm{PGD}_{2}$ & 351 & 271 \\
\hline $15 \mathrm{~d}-\Delta^{12,14} \mathrm{PGD}_{2}$ & 333 & 271 \\
\hline $\mathrm{PGE}_{2}$ & 351 & 315 \\
\hline $\mathrm{PGF}_{2 \alpha}$ & 353 & 193 \\
\hline 15-keto $\mathrm{PGF}_{2 \alpha}$ & 351 & 217 \\
\hline $\mathrm{PGJ}_{2}$ & 315 & 271 \\
\hline $\mathrm{PGK}_{2}$ & 349 & 205 \\
\hline $\mathrm{PGD}_{3}$ & 349 & 269 \\
\hline $\mathrm{PGE}_{3}$ & 349 & 269 \\
\hline $\mathrm{PGF}_{3 \alpha}$ & 351 & 193 \\
\hline 6-keto $\mathrm{PGF}_{1 \alpha}-\mathrm{d}_{4}$ & 373 & 211 \\
\hline $\mathrm{PGE}_{2}-\mathrm{d}_{4}$ & 355 & 275 \\
\hline $\mathrm{PGB}_{2}-\mathrm{d}_{4}$ & 337 & 179 \\
\hline $\mathrm{PGD}_{2}-\mathrm{d}_{4}$ & 355 & 275 \\
\hline $\mathrm{PGF}_{2 \alpha}-\mathrm{d}_{4}$ & 357 & 197 \\
\hline $\mathrm{PGJ}_{2}-\mathrm{d}_{4}$ & 319 & 275 \\
\hline $\mathrm{TXB}_{2}$ & 369 & 195 \\
\hline $\mathrm{TXB}_{3}$ & 367 & 169 \\
\hline $\mathrm{TXB}_{2}-\mathrm{d}_{4}$ & 373 & 173 \\
\hline $\mathrm{LTB}_{4}$ & 335 & 195 \\
\hline $\mathrm{LTC}_{4}$ & 624 & 272 \\
\hline $\mathrm{LTD}_{4}$ & 495 & 177 \\
\hline $\mathrm{LTE}_{4}$ & 438 & 235 \\
\hline $\mathrm{LTB}_{5}$ & 333 & 195 \\
\hline $\mathrm{LTB}_{4}-\mathrm{d}_{4}$ & 339 & 197 \\
\hline 5-HETE & 319 & 115 \\
\hline 8-HETE & 319 & 155 \\
\hline 9-HETE & 319 & 123 \\
\hline 11-HETE & 319 & 167 \\
\hline 12-HETE & 319 & 179 \\
\hline 15-HETE & 319 & 219 \\
\hline 19-HETE & 319 & 231 \\
\hline 20-HETE & 319 & 301 \\
\hline 5,6-DiHETE & 335 & 163 \\
\hline 5,15-DiHETE & 335 & 201 \\
\hline 8,15-DiHETE & 335 & \\
\hline 5,12-DiHETE & 335 & 195 \\
\hline 5-HрETE & 335 & 155 \\
\hline 12-НpETE & 335 & 153 \\
\hline 15-НpETE & 335 & 113 \\
\hline 5-OxoETE & 317 & 203 \\
\hline 12-OxoETE & 317 & 153 \\
\hline 15-OxoETE & 317 & \\
\hline 5-HETE- $\mathrm{d}_{8}$ & 327 & 116 \\
\hline 12 -HETE- $\mathrm{d}_{8}$ & 327 & 308 \\
\hline 15-HETE-d 8 & 327 & 226 \\
\hline 5,6-EET & 319 & 163 \\
\hline 8,9-EET & 319 & 155 \\
\hline 11,12-EET & 319 & 167 \\
\hline 14,15 -EET & 319 & 301 \\
\hline $5,6-E E T-d_{11}$ & 330 & 268 \\
\hline $14,15-E E T-d_{11}$ & 330 & 202 \\
\hline 5,6-DHET & 337 & 145 \\
\hline 8,9- DHET & 337 & 127 \\
\hline 11,12- DHET & 337 & 167 \\
\hline 14,15- DHET & 337 & 207 \\
\hline $\mathrm{LXA}_{4}$ & 351 & 115 \\
\hline $\mathrm{LXB}_{4}$ & 351 & 129 \\
\hline $\mathrm{LXA}_{4}-\mathrm{d}_{5}$ & 356 & 115 \\
\hline \multicolumn{3}{|l|}{ Docosanoids } \\
\hline RvD1 & 375 & 141 \\
\hline RvD5 & 359 & 199 \\
\hline MaR1 & 359 & 250 \\
\hline 10,17 -protectin & 359 & 153 \\
\hline 17-HDoHE & 343 & 201 \\
\hline 14-HDoHE & 343 & 161 \\
\hline
\end{tabular}

HODE, hydroxyoctadecadienoic acid; HDoHE, hydroxydocosahexaenoic acid; HETE, hydroxyeicosatetraenoic acid; DiHETE, dihydroxyeicosatetraenoic acid; HpETE, hydroperoxyeicosatetraenoic acid; OxoETE, oxoeicosatetraenoic acid; EET, epoxyeicosatrienoic acid; DHET, dihydroxyicosatrienoic acid; LX, lipoxin; LT, leukotriene; MaR, maresin; PG, prostaglandin; Rv, resolvin; TX, thromboxane.

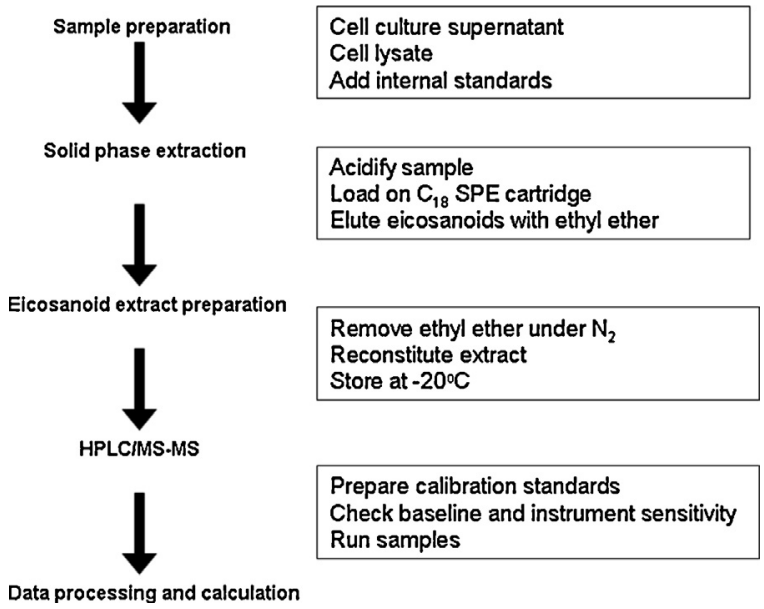

Fig. 3. Flow chart showing the main steps for the analysis of eicosanoid in cell system samples by LC-MS/MS.

\subsection{Normalization of the findings}

Although cell systems offer good standard and controlled conditions, eicosanoid concentrations in cell lysates or cell supernatants may differ depending upon different analytical and non-analytical factors including the cell model, notably the cellular enzymatic machinery the kind of stimulus used and the growth stage of the cells [64]. For these reasons, normalization of the analytical results to the cell number used and more frequently to the protein concentration measured in the samples is required. Table 1 and Table 3 present an overview of the LC-MS/MS methods used for analysis of eicosanoids in cell models and of the eicosanoids concentration measured by LC-MS/MS under the respective experimental conditions. Table 3 shows that eicosanoid concentration measured in cell cultures are in the range $10-500 \mathrm{pg} / \mathrm{mg}$ protein, $1-500 \mathrm{ng} / 10^{6}$ cells or $0.1-10 \mathrm{ng} / \mathrm{ml}$.

\section{Biological, pharmacological and nutritional applications of eicosanoid analysis by LC-MS/MS in cellular models}

The main steps and the workflow of a typical protocol for eicosanoid quantification in cell cultures by LC-MS/MS are shown in Fig. 3. Overall, cell culture samples are spiked with is a mixture of stable-isotope labelled eicosanoids, commonly deuterated compounds. Samples are then acidified to $\mathrm{pH} 3.0$ to allow for complete protonation of the carboxylic groups of the eicosanoids and maximum extraction recovery for instance by SPE. Endogenous analytes and respective IS present in the resulting eicosanoid extract are partially separated by HPLC and then by MS/MS in the MRM mode.

The LC-MS/MS methodology has been shown by many groups to be a useful analytical tool for the quantitative determination of eicosanoids and related compounds in cell cultures and to understand the role of these compounds in the maintenance of homeostasis in various processes. For instance, the role of eicosanoids has been investigated in intestinal epithelial growth/apoptosis [8], in mesenchymal stem cell culture [67], in two phenotypically different mast cell populations on intestinal inflammatory response [68], and in blood coagulation [69]. The LC-MS/MS approach has not only been used to evaluate the role of eicosanoids in disease states [70], but also to study the role of eicosanoids in the pathogenesis of numerous diseases. For instance, Michaelis et al. [45] reported a role for EETs in relation to migration and angiogenesis under hypoxic conditions in bovine retinal endothelial cell cultures. More recently, LC-MS/MS has been used to study the involvement of oxylipins in cardiac surgery [34], how adipocytes 
Table 3

Overview of eicosanoid concentrations obtained by HPLC-MS/MS in different cell systems.

\begin{tabular}{|c|c|c|c|c|c|c|c|}
\hline & $\begin{array}{l}\text { Human lung } \\
\text { cancer cells } \\
\left(\text { A549) }{ }^{\mathrm{a}}[50]\right.\end{array}$ & $\begin{array}{l}\text { Human } \\
\text { prostate cancer } \\
\text { cells (PC-3-S) } \\
{[47]}\end{array}$ & $\begin{array}{l}\text { Human } \\
\text { umbilical vein } \\
\text { cell line } \\
\left(\text { EA.hy926) }{ }^{\mathrm{c}}[65]\right.\end{array}$ & $\begin{array}{l}\text { Murine } \\
\text { fibroblasts } \\
\text { (3T6) [36] }\end{array}$ & $\begin{array}{l}\text { Cod head } \\
\text { kidney } \\
\text { leukocytes [66] }\end{array}$ & $\begin{array}{l}\text { Human colon } \\
\text { adenocarci- } \\
\text { noma cells } \\
(\text { Caco- } 2)[41]\end{array}$ & $\begin{array}{l}\text { Human foam } \\
\text { macrophages [38] }\end{array}$ \\
\hline $\mathrm{PGE}_{2}$ & $50 \mathrm{ng} / 10^{6}$ cells & $375 \mathrm{pg} / \mathrm{mg}$ prot & & $0.4^{\mathrm{d}} / 1.6^{\mathrm{e}} \mathrm{ng} / \mathrm{ml}$ & $1^{\mathrm{d}} / 4^{\mathrm{f}} \mathrm{ng} / \mathrm{ml}$ & $0.5^{\mathrm{d}} / 2^{\mathrm{e}} \mathrm{ng} / \mathrm{ml}$ & $126^{\mathrm{d}} / 149^{\mathrm{g}} \mathrm{ng} / \mathrm{ml}$ \\
\hline $\mathrm{PGD}_{2}$ & & $150 \mathrm{pg} / \mathrm{mg}$ prot & & & & & \\
\hline 6-keto-PGF $1 \alpha$ & & $25 \mathrm{pg} / \mathrm{mg}$ prot & & & & & \\
\hline $\mathrm{PGF}_{2} \alpha$ & & $25 \mathrm{pg} / \mathrm{mg}$ prot & & & & & \\
\hline $\mathrm{PGE}_{3}$ & & & & & $0.5^{\mathrm{d}} \mathrm{ng} / \mathrm{ml}$ & & $222^{\mathrm{d}} / 253^{\mathrm{g}} \mathrm{ng} / \mathrm{ml}$ \\
\hline $\mathrm{LTB}_{4}$ & & & & $0.2^{\mathrm{d}} / 0.3^{\mathrm{e}} \mathrm{ng} / \mathrm{ml}$ & $3^{\mathrm{d}} / 18^{\mathrm{f}} \mathrm{ng} / \mathrm{ml}$ & $0.4^{\mathrm{d}} / 2^{\mathrm{e}} \mathrm{ng} / \mathrm{ml}$ & $7.8^{\mathrm{d}} / 9.1^{\mathrm{g}} \mathrm{ng} / \mathrm{ml}$ \\
\hline $\mathrm{LTB}_{5}$ & & & & & $4^{\mathrm{d}} \mathrm{ng} / \mathrm{ml}$ & & $23^{\mathrm{d}} / 23^{\mathrm{g}} \mathrm{ng} / \mathrm{ml}$ \\
\hline 5-HETE & $5 \mathrm{ng} / 10^{6}$ cells & & $450 \mathrm{ng} / 10^{6}$ cells & $1^{\mathrm{d}} / 2.7^{\mathrm{e}} \mathrm{ng} / \mathrm{ml}$ & & $2.6^{\mathrm{d}} / 7.8^{\mathrm{e}} \mathrm{ng} / \mathrm{ml}$ & $1270^{\mathrm{d}} / 1245^{\mathrm{g}} \mathrm{ng} / \mathrm{ml}$ \\
\hline 8-HETE & & & $50 \mathrm{ng} / 10^{6}$ cells & & & & $506^{\mathrm{d}} / 508^{\mathrm{g}} \mathrm{ng} / \mathrm{ml}$ \\
\hline 11-HETE & $12 \mathrm{ng} / 10^{6}$ cells & & $50 \mathrm{ng} / 10^{6}$ cells & & & & \\
\hline 12-HETE & & & $50 \mathrm{ng} / 10^{6}$ cells & $0.9^{\mathrm{d}} / 2.2^{\mathrm{e}} \mathrm{ng} / \mathrm{ml}$ & & $1.3^{\mathrm{d}} / 3.7^{\mathrm{e}} \mathrm{ng} / \mathrm{ml}$ & $558^{\mathrm{d}} / 586^{\mathrm{g}} \mathrm{ng} / \mathrm{ml}$ \\
\hline 15-HETE & & & $300 \mathrm{ng} / 10^{6}$ cells & $0.5^{\mathrm{d}} / 2.2^{\mathrm{e}} \mathrm{ng} / \mathrm{ml}$ & & $3.4^{\mathrm{d}} / 8^{\mathrm{e}} \mathrm{ng} / \mathrm{ml}$ & $970^{\mathrm{d}} / 1061^{\mathrm{g}} \mathrm{ng} / \mathrm{ml}$ \\
\hline 5,6-EET & & & $1 \mathrm{ng} / 10^{6}$ cells & & & & $114^{\mathrm{d}} / 121^{\mathrm{g}} \mathrm{ng} / \mathrm{ml}$ \\
\hline 8,9-EET & & & $15 \mathrm{ng} / 10^{6}$ cells & & & & $277^{\mathrm{d}} / 274^{\mathrm{g}} \mathrm{ng} / \mathrm{ml}$ \\
\hline 11,12 -EET & & & $2 \mathrm{ng} / 10^{6}$ cells & & & & $472^{\mathrm{d}} / 474^{\mathrm{g}} \mathrm{ng} / \mathrm{ml}$ \\
\hline 14,15-EET & & & $17 \mathrm{ng} / 10^{6}$ cells & & & & $301^{\mathrm{d}} / 400^{\mathrm{g}} \mathrm{ng} / \mathrm{ml}$ \\
\hline 13-HODE & & & & $0.9^{\mathrm{d}} / 3^{\mathrm{e}} \mathrm{ng} / \mathrm{ml}$ & & & \\
\hline
\end{tabular}

a Eicosanoids determined after the incubation of the cells with $125 \mu \mathrm{M}$ AA for $10 \mathrm{~min}$

b With $10 \mu \mathrm{M}$ AA for $10 \mathrm{~min}$.

c With $30 \mu \mathrm{M}$ AA for $5 \mathrm{~min}$.

d In the absence of any growth factor.

e With $10 \%$ FBS for $24 \mathrm{~h}$.

f With $50 \mu \mathrm{M}$ AA for $24 \mathrm{~h}$.

g With $1 \mu \mathrm{g} / \mathrm{ml}$ LPS for $24 \mathrm{~h}$ and then stimulated with AA, DHA or EPA for $2 \mathrm{~h}$.

release cytokines that are involved in obesity and metabolic syndrome [71], or in hepatic oxidative stress/inflammation [72]. Cell culture systems and LC-MS/MS have also been used to study the role of oxylipins as biomarkers of oxidative stress in specific diseases in which the AA cascade is involved [73-77].

Inhibitors of enzymes involved in the AA cascade have been used as key targets for non-steroidal anti-inflammatory drug (NSAID) design. Although the response of individual eicosanoids to drugs has been studied, the modulation of eicosanoid biosynthesis has yet to be evaluated systematically. Cell cultures and LC-MS/MS are currently being used to study the effects of new drugs/compounds on the eicosanoid synthesis in AA pathways. These methodologies provide comprehensive information about the effects of a drug on all AA pathways and the eicosanoid synthesized [33]. Recently, several new modified NSAIDs have been reported that exert different effects on AA cascade pathways. Thus, El Elkady et al. [78] developed specific prostaglandin E synthase-1 inhibitors, and Chattopadhyay et al. [79] reported a new form of aspirin, i.e., NOSHaspirin, which releases both nitric oxide (NO) and hydrogen sulfide $\left(\mathrm{HS}^{-}\right)$.

Interestingly some eicosanoids are also used as drugs. A good example for such eicosanoids is misoprostol, i.e., prostaglandin $E_{1}\left(P_{G E}\right)$. It was indicated for treating peptidic ulcers and then adopted in the 1990s for use as uterotonic in the management of postpartum hemorrhage [80]. Cell culture and LC-MS/MS have been shown to be suitable approaches for performing in vitro pharmacokinetic studies of such drugs [81].

In nutritional science, health has long been studied in relation to the quantity and type of the fat (lipid) consumed. One particular area of interest here concerns the balance between n- 3 and n- 6 fatty acids and the biology of new mediators such as lipoxins and resolvins, mediators involved in the "resolution of inflammation" [14]. This research area is rapidly growing thanks to the LC-MS/MS technique $[38,40]$. Potential health benefits in terms of a reduced incidence of cardiovascular events have been shown to be associated with the consumption of certain types of oil such as virgin olive oil, and nuts [82]. With regard to nutritional interventions it is important to understand the concomitant shifts in lipid balance and the production of down-stream lipid mediators such as eicosanoids and other oxylipins. Several recent papers report findings that illustrate the complexity of this topic [38,83]. Comprehensive quantitative measurement of lipids in cell systems will, in conjunction with in vivo assays and clinical studies, help to elucidate and to define the clinical pharmacology of dietary bioactive compounds and, potentially, to establish beneficial nutritional habits.

\section{Conclusion}

The eicosanoids comprise a large family of structurally closely related and potent bioactive lipids with numerous biological roles. In this article we reviewed the particular importance of the LCMS/MS methodology to unequivocally identify and accurately quantify a wide range of eicosanoids in cell models using stableisotope labeled eicosanoids as internal standards. Our examination of reported studies in this area indicates that LC-MS/MS is a versatile analytical tool for the simultaneous and rapid analysis of multiple PUFA-derived metabolites in cell culture samples. LCMS/MS provides useful information about the implication and role of eicosanoids in cellular processes such as inflammation and cancer. LC-MS/MS and cell models also help better understand the effects of nutrition and drugs on multiple eicosanoids-related pathways. We conclude that the LC-MS/MS methodology is a versatile and reliable analytical tool for the study of the pathophysiology of eicosanoids in cell models in various conditions.

\section{Acknowledgements}

This research was supported by Spanish Ministry of Science and Innovation (BFU2007-61727/BFI) and by the Generalitat (Autonomous Government) of Catalonia (2009SGR0438). The authors would like to express their appreciation to Dr. Dimitrios Tsikas for the substantial contributions he had made to this work while serving as editor. The Language Services of the Universitat de Barcelona are also gratefully acknowledged. 


\section{References}

[1] C.D. Funk, Science 294 (2001) 1871-1875.

[2] M.P. Wymann, R. Schneiter, Nat. Rev. Mol. Cell Biol. 9 (2008) 162-176.

[3] M.W. Buczynski, D.S. Dumlao, E.A. Dennis, J. Lipid Res. 50 (2009) 1015-1038.

[4] M.C. Cathcart, J. Lysaght, G.P. Pidgeon, Cancer Metastasis Rev. 30 (2011) 363-385.

[5] E.R. Greene, S. Huang, C.N. Serhan, D. Panigrahy, Prostaglandins Other Lipid Mediat. 96 (2011) 27-36.

[6] J.J. Moreno, Biochem. Pharmacol. 77 (2009) 1-10.

[7] C.N. Serhan, N. Chiang, T.E. Van Dyke, Nat. Rev. Immunol. 8 (2008) 349-361.

[8] R. Ferrer, J.J. Moreno, Biochem. Pharmacol. 80 (2010) 431-438.

[9] P. Montuschi, Mini Rev. Med. Chem. 8 (2008) 647-656.

[10] N. Li, J.Y. Liu, H. Qiu, T.R. Harris, P. Sirish, B.D. Hammock, N. Chiamvimonuat, Congest. Heart Fail 17 (2011) 42-46.

[11] S.L. Lundström, B. Levänen, M. Nording, A. Kiepczynska-Nyström, M. Sköld, J.Z Haeggström, J. Grunewald, M. Suartengreen, B.D. Hammock, B.M. Larsson, A Eklund, A.M. Wheelock, C.E. Wheelock, PloS One 6 (2011) e23864.

[12] M. Barreto, M.P. Villa, C. Olita, S. Mantella, G. Ciabattoni, P. Montuschi, Chest 135 (2009) 66-73.

[13] V. Lucidi, G. Ciabattoni, S. Bella, P.J. Barnes, P. Montuschi, Free Rad. Biol. Med. 45 (2008) 913-919.

[14] C.N. Serhan, N.A. Petasis, Chem. Rev. 111 (2011) 5922-5943.

[15] N. Youhnowski, D. Schulz, C. Schwarz, G. Spiteller, K. Schubert, Z. Naturforsch C. 58 (2003) 268-276.

[16] C. Mesaros, S.H. Lee, I.A. Blair, J. Chromatogr. B 877 (2009) 2736-2745.

[17] H.E. Grates, R.M. McGowen, S.V. Gupta, J.R. Falck, T.R. Brown, D.M. Callewaert, D.M. Sasaki, J. Biosci. 28 (2003) 109-113.

[18] J.H. Dahl, R.B. van Breemen, Anal. Biochem. 404 (2010) 211-216.

[19] D. Tsikas, J. Chromatogr. B 878 (2010) 133-148.

[20] R.C. Murphy, S. Hammarström, B. Samuelsson, Proc. Natl. Acad. Sci. USA 76 (1979) 4275-4279.

[21] H. Yue, K.I. Strauss, M.R. Borenstein, M.F. Barbe, L.J. Rossi, S.A. Jansen, J. Chromatogr 25 (2004) 267-277.

[22] V.A. VanderNoot, M. VanRollins, Anal. Chem. 74 (2002) 5859-5870.

[23] M. VanRollins, V.A. VanderNoot, Anal. Biochem. 313 (2003) 106-116.

[24] J.M.W. Van den Ouweland, I.P. Kema, J. Chromatogr. B 883-884 (2012) 18-32.

[25] M.R. Wenk, Nat. Rev. Drug Discov. 4 (2005) 594-609.

[26] H.A. Brown, Lipidomics and bioactive lipids: Mass spectrometry-based lipid analysis, Academic Press, San Diego, California, 2007.

[27] X. Han, K. Yang, R.W. Gross, Mass Spectrom. Rev. 31 (2012) 134-178.

[28] C.E. Wheelock, V.M. Goss, D. Balgoma, B. Nicholas, J. Brandsma, P.J. Skipp, D. Burg, A. D'Amico, I. Horvath, A. Chaiboonchoe, H. Ahmed, S. Ballereau, C. Rossios, K.F. Chung, P. Montuschi, S.J. Fowler, I.M. Adcock, A.D. Postle, S.E. Dahlén, A. Rowe, P.J. Stek, C. Auffray, R. Djukanovic, Eur. J. Respir. 42 (2013) $802-825$.

[29] J. Yang, K. Schmelzer, K. Georgi, B.D. Hammock, Anal. Chem. 81 (2009) 8085-8093.

[30] S.R. Dahl, C.R. Kleiveland, M. Kassem, T. Lea, E. Lundanes, T. Greibrokk, J. Sep. Sci. 31 (2008) 2627-2633.

[31] H. Cao, L. Xiao, G.Y. Park, X. Wang, A.C. Azim, J.W. Christman, R.B. van Breemen, Anal. Biochem. 372 (2008) 41-51.

[32] S. Rinne, C. Ramstad Kleiveland, M. Kassem, T. Lea, E. Lundanes, T. Greibrokk, J Sep. Sci. 30 (2007) 1860-1869.

[33] C. He, W.Y. Wu, Y. Lai, Z. Cai, Y. Liu, L. Lai, Mol. Biosyst. 8 (2012) 1585-1594

[34] K. Strassburg, A.M. Huijbrechts, K.A. Kortekaas, J.H. Lindeman, T.L. Pedersen, A. Dane, R. Berger, A. Brenkman, T. Hankemeier, J. van Duynhoven, E. Kalkhoven, J.W. Newman, R.J. Vreeken, Anal. Bioanal. Chem. 404 (2012) 1413-1426.

[35] H. Yue, S.A. Jansen, K.I. Strauss, M.R. Borenstein, M.F. Barbe, I.J. Rossi, E. Murphy, J. Pharm. Biomed. Anal. 43 (2007) 1122-1134.

[36] R. Martin-Venegas, R. Casillas, O. Jáuregui, J.J. Moreno, J. Pharm. Biomed. Anal. 56 (2011) 976-982

[37] D.D. Shinde, K.B. Kim, K.S. Oh, N. Abdalla, K.H. Liu, S.K. Bae, J.H. Shon, H.S. Kim, D.H. Kim, J.G. Shin, J. Chromatogr. B 911 (2012) 113-121.

[38] P. Le Faouder, V. Baillif, I. Spreadbury, J.P. Motta, P. Rousset, G. Chene, C. Guigne, F. Tercé, S. Vanner, N. Vergnolle, J. Bertrand-Michel, M. Dubourdeau, N. Cenac, J. Chromatogr. B 932 (2013) 123-133.

[39] Y.J. Xu, W.E. Ho, F. Xu, T. Wen, C.N. Ong, Prostaglandins Lipid Mediat. 106 (2013) 29-36.

[40] D. Balgoma, J. Larsson, J. Rokach, J.A. Lawson, K. Daham, B. Dahlen, S.E. Dahlen, C.E. Wheelock, Anal. Chem. 85 (2013) 7866-7874

[41] M. Cabral, R. Martín-Venegas, J.J. Moreno, Int. J. Biochem. Cell Biol. 45 (2013) 1620-1628

[42] X. Liu, S. Zhang, J.S. Arora, N.W. Snyder, S.J. Shah, I.A. Blair, Chem. Res. Toxicol. 24 (2011) 2227-2236.
[43] C. Mesaros, S.H. Lee, I.A. Blair, Rapid Commun. Mass Spectrom. 24 (2010) 3237-3247.

[44] S. Mulugeta, T. Suzuki, N.T. Hernandez, M. Griesser, W.E. Boeglin, C. Schneider, J. Lipid Res. 51 (2010) 575-585.

[45] U.R. Michaelis, N. Xia, E. Barbosa-Sicard, J.R. Falck, I. Fleming, Invest. Ophthalmol. Vis. Sci. 49 (2008) 1242-1247.

[46] C.P. Schroeder, P. Yang, R.A. Newman, R. Lotan, Cancer Biol. Ther. 3 (2004) 847-852.

[47] K. Nithipatikom, N.D. Laabs, M.A. Isbell, W.B. Campbell, J. Chromatogr. B 785 (2003) 135-145.

[48] M. Takabatake, T. Hishinuma, N. Suzuki, S. Chiba, H. Tsukamoto, H. Nakamura T. Saga, Y. Tomioka, A. Kurose, T. Sawai, M. Mizugaki, Prostaglandins Leukot. Essent. Fatty Acids 67 (2002) 51-56.

[49] P. Yang, E. Felix, T. Madden, S.M. Fischer, R.A. Newman, Anal. Biochem. 308 (2002) 168-177

[50] E.C. Kempen, P. Yang, E. Felix, T. Madden, R.A. Newman, Anal. Biochem. 297 (2001) 183-190

[51] C.S. Newby, A.I. Mallet, Rapid Commun. Mass Spectrom. 11 (1997) $1723-1727$.

[52] F.A. Fitzpatrick, M.A. Wynalda, J. Biol. Chem. 258 (1983) 11713-11718.

[53] R. Schmidt, O. Coste, G. Geisslinger, J. Chromatogr. B 826 (2005) 188-197.

[54] K.R. Maddipati, S.L. Zhou, Prostaglandins Other Lipid Mediat. 94 (2011) $59-72$.

[55] T. Oe, B.L. Ackermann, K. Inoue, M.J. Berna, C.O Graner, V. Gelfanova, R.A. Dean, E.R. Siemens, D.M. Holtzman, M.R. Farlow, I.A. Blair, Rapid Commun. Mass Spectrom. 20 (2006) 3723-3735.

[56] P.L. Kole, G. Venkatesh, J. Kotecha, R. Sheshala, Biomed. Chromatogr. 25 (2011) 199-217.

[57] E. Chambers, D. Wagrowski-Diehl, Z. Lu, J. Mazzeo, J. Chromatogr. B 852 (2007) 22-34.

[58] L.A. Moraes, R.M. Giner, M.J. Paul-Clark, M. Perretti, D. Perrett, Biomed. Chromatogr. 18 (2004) 64-68.

[59] D.B. Bittleman, T.B. Casale, Am. J. Respir. Cell Mol. Biol. 12 (1995) 260-267.

[60] M. Cabral, R. Martin-Venegas, J.J. Moreno, Am. J. Physiol. Gastroenterol. (2014), submitted.

[61] P. Montuschi, J. Chromatogr. B 877 (2009) 1272-1280.

[62] R.C. Murphy, R.M. Barkley, K. Zemski Berry, J. Hankin, K. Harrison, C. Johnson, J. Krank, A. McAnoy, C. Uhlson, S. Zarini, Anal. Biochem. 346 (2005) $1-42$.

[63] U.S. Department of Health and Human Services, Food and Drug Administration (FDA), Center for Drug Evaluation and Research (CDER). Guidance for Industry, Bioanalytical Method Validation. www.fda.gov/guidance/4252fnl.htm

[64] R. Martín-Venegas, S. Roig-Pérez, R. Ferrer, J.J. Moreno, J. Lipid Res. 47 (2006) 1416-1423.

[65] V. Zelinski, J. Borlak, Xenobiotica 35 (2005) 811-823.

[66] P. Araujo, S. Janagap, E. Holen, J. Chromatogr. A 1260 (2012) 102-110.

[67] C. Ferreiro-Vera, J.M. Mata-Granados, F. Priego-Capote, J.M. Quesada-Gómez M.D. Luque de Castro, Anal. Bioanal. Chem. 399 (2011) 1093-1103.

[68] S.L. Lundström, R. Saluja, M. Adner, J.Z. Haeggström, G. Nilsson, C.E. Wheelock, J. Lipid Res. 54 (2013) 116-126.

[69] T. Matsunobu, T. Okuno, C. Yokoyama, T. Yokomizo, J. Lipid Res. 54 (2013) 2979-2987.

[70] S.C. Tucker, K.V. Honn, Biochem. Pharmacol. 85 (2013) 673-688.

[71] J. Claria, B.T. Nguyen, A.L. Madenci, C.K. Ozaki, C.N. Serhan, Am. J. Physiol. Cell Physiol. 304 (2013) C1141-C1149.

[72] T. Sicilia, A. Mally, U. Schauer, A. Pähler, W. Völkel, J. Chromatogr. B 861 (2008) 48-55.

[73] F. Cai, Y.M. Dupertuis, C. Pichard, Curr. Opin. Clin. Nutr. Metab. Care 15 (2012) 99-106.

[74] S.S. Davies, L.J. Roberts II, Free Rad. Biol. Med. 50 (2011) 559-566.

[75] S. Gamagedara, Y. Ma, Bioanalysis 18 (2011) 2129-2142

[76] N. Rabinovitch, Immunol. Allergy Clin. North Am. 32 (2012) 433-445.

[77] T.T. Reed, Free Rad. Biol. Med. 51 (2011) 1302-1319.

[78] M. Elkady, R. Niess, A.M. Schaible, J. Bauer, S. Luderer, J. Med. Chem. 55 (2012) 8958-8962.

[79] M. Chattopadhyay, R. Kodela, K.R. Olson, K. Kashfi, Biochem. Biophys. Res. Commun. 419 (2012) 523-528.

[80] H. El-Refaey, P. O’Brien, W. Morafa, J. Walder, C. Rodeck, Br. J. Obstet. Ginaecol. 104 (1997) 336-339

[81] D. Vijaya Bharathi, B. Jagadeesh, K.K. Hotha, U. Patil, I. Bhushan, J. Chromatogr. B 879 (2011) 2827-2833.

[82] R. Estruch, E. Ros, J. Salas-Salvadó, M.I. Covas, N. Engl. J. Med. 368 (2013) $1279-1290$.

[83] A.P. Neilson, J. Ren, Y.H. Hong, A. Sen, W.L. Smith, D.E. Brenner, Z. Djuric, Nutr Cancer 64 (2012) 163-172. 